\title{
LINNAEAN ANNIVERSARY CELEBRATIONS
}

\author{
By DR. J. RAMSBOTTOM
}

\begin{abstract}
A $\mathrm{S}$ was to be expected, the Swedish celebrations of the 250th anniversary of the birth of Linnaeus were befitting to the memory of a worldfamous scientist, and a national hero. A new statue -a copy of the one at Stockholm-was set up at Upsala, a medal was struck, telegraph forms bore a fine coloured representation of Linnaea borealis, special postage stamps were issued, and numerous works both by and on Linnaeus were displayed in the book-shops.

The celebrations proper began at his birthplace, Råshult, on May 23 (O.S. May 11), his birthday, and May 24, long regarded as such by, for example, the Linnean Society of London, owing to confusion when the Swedish calendar was changed. The University of Upsala, where Linnaeus was professor of medicine and botany $(1741-78)$ and three times rector magnificus, as well as paying special tribute in the end-of-term ceremonies, arranged a symposium on "Systematics of To-day" (May 28-30), which was attended by about thirty foreign guests.

Those attending were welcomed at an opening ceremony in what was formerly the orangery of the old University Botanic Garden by the Rector Magnificus of the University of Upsala and by the Chancellor of the Swedish Universities, in short speeches. Then the president of the symposium, Prof. J. A. Nannfeldt, gave a brief address in which he spoke of Linnaeus's attitude to Nature, his concept of species and the appropriateness of the meeting as part of the Upsala celebrations. Afterwards a walk was taken round the Garden, again arranged as by Linnaeus, and a short visit to the adjoining professor's house, now used as a Linnaean museum. The attractive large yellow-flowered Corydalis nobilis was growing abundantly as a weed in the garden, as elsewhere in Upsala: it was introduced among seeds of Dicentra spectabilis sent to Linnaeus from Siberia.
\end{abstract}

The symposium proper was held at the University. Probably most people doubted whether a programme of twenty-seven papers, with discussions, could be crammed into four sessions. Each speaker had been allotted fifteen minutes, and all loyally kept to this, occasionally reminded of the passage of time by a sort of traffic-signal system in full view of the audience, with an accompanying buzz-an international selfdenying ordinance with consequent smooth running, and general satisfaction: the improbable had been achieved. The opening paper was by E. Mayr (United States) on "The Evolutionary Significance of the Systematic Categories". The primary object of systematics has always been to permit grouping of the bewildering number of natural entities into collective units-to make order out of chaos. This seemingly purely practical task can be carried out in different ways depending on the basic philosophy adopted. Though the practical aims of taxonomists are still the same as in the time of Linnaeus, the underlying philosophy has changed drastically. There are two essential reasons for this : (1) the acceptance of the theory of evolution and, far more important, (2) the replacement of typological thinking by popu- lations thinking. These are by no means two aspects of the same concept.

A species is a group of interbreeding populations. Individuals of which a species is composed are the visible expression and temporary containers of the 'gene pool' of the species. This pool is sharply limited to genes which can harmoniously combine into genotypes and produce successful phenotypes. Harmonious gene pools require protection against outside disturbance-the so-called isolating mechanisms. The limitation of the gene pool sharply restricts the ecological potentialities of a species. By reason of its limited genetic endowment each species is specialized to a greater or lesser degree : every new gene pool, every incipient new species, and every new species is an ecological experiment; a possibility of entering a new adaptive zone. This is the great evolutionary significance of the species.

There is a certain collective advantage in the stability of phenotypes. There is a 'developmental homœostasis' which permits of a great deal of genetic reconstruction without major morphological reconstruction. Once a successful phenotype has been evolved there will be an evolutionary tendency to preserve it. There is an optimum phenotype for a particular ecological niche.

Each morphological type is the produce of a long process of adaptation for a specific environment, namely, that occupied by the given taxonomic category. Each taxon is thus not only a morphological phenomenon or a genetic phenomenon, but also an ecological phenomenon. The re-organization of the gene complex which such an evolutionary adaptability entails cannot be reversed.

Julian S. Huxley (Great Britain) spoke on "Grades as an Auxiliary Method in Taxonomy". The aim of most post-Darwinian taxonomy has been to express natural (phyletic) relationships: the taxonomic units (genus, order, class, etc.) are assumed to denote monophyletic groups. Often, however, such groups have turned out to be certainly, or probably, di- or poly-phyletic (for example, Subholostei, Gryphaea). They should, therefore, be called grades, not monophyletic units.

Further, the co-existence, in all evolutionary processes, of improvement (anagenesis) as well as diversification by splitting (cladogenesis) necessitates the erection of a two-way taxonomic system, classifying assemblages by anagenetic grades as well as by cladogenetic monophyletic groups, for which the general term clades may be suggested.

In point of fact most taxonomic units have been recognized as such because they represent persistent grades of organization, while phylogeny is more speculative and is, for the most part, a matter not of observation but of deduction. In any event, anagenetic units (grades) are just as 'natural' or readily delimitable as monophyletic units (clades). Indeed, many taxa are simultaneously both grades and clades (for example, Amniota, Monotremata, Dipneumonina, Equus). Others, however, are only (polyphyletic) grades (for example, Metozoa, Teleostei, and various 
'genera' such as Merychippus or Cephalaspis). The human stock is properly definable both as a minor clade (family Hominidae) and a major grade (Psychozoa).

G. Heberer (Western Germany) followed with "Zum Problem den additiven Typogenese"-on much the same general lines as the two previous papers. It was interesting to note the importance all three speakers placed on the researches of the American geologist, G. G. Simpson.

It was now the turn of the eryptogamic botanists, Roger Heim (France) dealing with "Les critères d'ordre chimique dans l'étude des affinités chez les Macromycètes". He examined in what degree the occurrence of certain chemical substances in fungi (either immediate products such as glycogen, chitin and cellulose, mannitol, trehalose, or pigments dissolved in vacuoles and fat globules in cells) can be used for supporting views in the general systematy of Mycetes. He showed that in certain cases-crystallized carotinic chondriocontes of spermatophytes and of fungi-such criteria have no taxonomic value. On the other hand, the presence or absence of a substance in a given group may provide strong confirmatory evidence of its status : such are the intercellular pigments of agarics with coloured spores, diphenylbenzoquinonic pigments. He gave examples of genera in which certain chemical substances are found in some only of the species but where all the species are obviously intimately related. $\mathrm{H}_{\Theta}$ also gave examples of the strong correlation which can be seen between chemistry and certain anatomical structures. In his view biochemical criteria have a part to play in the controversies, hypotheses and confirmations of systematies, with its ultimate aim of a natural classification.

J. Feldmann (France) in "Remarques sur la Systématique actuelle des Algues" stressed the importance of eytological and biochemical characters for distinguishing large divisions (phyla) of algae as well as for characterizing orders. He showed, as an example, how the utilization of these characters during the past twenty years had brought about the splitting up of the Siphonales, formerly considered to be homogeneous.

Comparing systematics with taxonomy, the aim of which is essentially practical, he showed that in algae the search for natural affinities, the object of systematics, should make use of characters drawn from the living matter itself (morphology of the cellular constituents and biochemical peculiarities) rather than those furnished by morphology, anatomy and mode of reproduction. By convergence such characters can be the same in groups having no real affinities.

R. Tuomikoski (Finland) followed with a research summary "Über den heutigen Stand der Laubmoossystematik". Mosses are easy to collect and examine under the microscope so that at first their study made good progress along morphological lines. This resulted in their classification becoming more or less stereotyped, and during the past twenty years little research has been carried out to bring it more in line with modern ideas.

R. Pichi-Sermolli (Italy) gave an outline of "The Higher 'Taxa of the Pteridophyta and their Classification", making several proposals for modification and rearrangement.

The afternoon session opened with a philosophical discussion by B. Rensch (Westerm Germany) on "Die ideale Artbeschreibung".
I. Manton (Great Britain) urged that "The Concept of the Aggregate Species" should be used in floras, illustrating her remarks by reference to her work on Polypodium. The aggregate species $P$. vulgare is composed of $P$. australe, $2 n$ chromosomes with a genotypic composition one might call $B$; $P$. vulgare s.s., $4 n$ chromosomes with a genotype $A C$; and $P$. interjectum, $6 n$ chromosomes with a genotype $A B C$. A second aggregate species would be $P$. virginicum with a microspecies with $2 n$ (genotype $A$ ), and another with $4 n$ (genotype $A D$ ).

R. C. Rollins (United States) in "Some Considerations of the Comparative Systematics of Vascular Plant Species" stressed the importance of comparative systematics in flowering plants, emphasizing that no single set of principles covers all the different types of variation which are encountered even within relatively narrow alliances. He instanced two genera of Cruciferae, Lesquerella and Leavenworthia, each with four species, having a striking parallel distribution in Tennessee. The variation pattern in these two genera, annuals occupying open habitats, is totally different. In Lesquerella the species are vicarious, and when artificially brought together, freely form hybrids, indicating the total lack of genetical sterility barriers. In Leavenworthia the species are sympatric, and highly incompatible with each other.

C. G. G. J. van Steenis (Holland) spoke on "Specific Delimitation, with Special Reference to Tropical Plants". He reviewed how far modern detailed research in genetics, experimental morphology, karyology and biochemistry has affected the basic value of the Linnean species. Though there is greatly increased insight of intraspecific structure the Linnean concept has been confirmed and has lost nothing of its actuality. The delimitation of genera and species is still the keystone of taxonomy, affecting botany in all its branchespure and applied. From various points of view it is most unfortunate that botanical science in general, and taxonomy in particular, were not developed in the tropics instead of in countries with depauperated floras and disturbed vegetation. Systematists investigating tropical floras are concerned at the immense flow of experimental research which, while tending to undermine the species concept, simultaneously introduces 'characters' and delimitations which the systematist can neither test nor judge on their intrinsic merits.

W. Ludwig (Western Germany) then gave a paper "Artbegriff und Evolution der Art unter dem Aspect E. Geoffroys (Geoffroyismus)".

The next morning's session began with J. Clausen (United States) on "Function and Evolution of Ecotypes, Ecospecies and other Natural Entities". Geneticecologic experiments have shown that morphological and ecological characters that adjust ecological races to the environment are governed by fairly complex systems of genes composed of genes of the multiple kind which may have additive, subtractive, complementary, or epistatic effects in various proportions. The genes that regulate the individual character are usually located on different chromosomes, enabling fairly free recombination. They are distributed to the ecological races of a species in such a manner that one race may possess the genetic key that unlocks the heredity that is stored in another race. Interracial crossing accordingly results in the release of variability, in transgressive segregation, and in hybrid vigour. 
Some of the genes that regulate different characters, however, are located on the same chromosomes, and accordingly cause moderate genetic linkage between distinguishing characters. The linkage is loose because only some of the genes of the system are linked. Such a genetic structure causes moderate genetic coherence, and permits moderate genetic recombination between ecological races. Ecological races, morphological subspecies, and closely related species function, therefore, as gene pools that store the potential variability of the genus in recognizable evolutionary entities or taxa, dynamic and flexible. Their genes regulate balanced processes adjusted to the seasonal and diurnal rhythms of the environment, an adjustment delicately balanced and requiring generations for development. A moderate genetic coherence is therefore an evolutionary necessity for proper survival. Natural selection has accordingly favoured such entities that possessed genetic struetures sufficiently rigid to reproduce themselves as long as the environment remained essentially the same and that were sufficiently flexible to permit them to change in periods of geologic revolution.

W. B. Turrill (Great Britain) then considered "Genetic Variation within Taxonomic Species", taking most of his illustrations from Silene maritima and $S$. vulgaris. $H_{e}$ emphasized the importance of habit characters as separating ecologically the two species and sub-species within them. Some of the variations experimentally proved to be genetical were definitely of survival value, others were deleterious, and others were doubtfully of survival value under the conditions now favoured by the different taxa. Some of the characters appear to be neutral in the sense of producing more or less balanced polymorphisms in many populations. The importance of considering the phenotype as a whole should always be kept in mind when survival value is being investigated.

J. Heslop Harrison (Northern Ireland) followed with "Ecological Variation and Ethological Isolation". Since the breeding system in a plant species is a dominant factor in determining its capacity for race formation, it is to be expected that differences will be found between anemophilous and entomophilous species in their patterns of infra-specific variation. In species which are specialized for a limited range of pollinators, persistent assortative pollination ('homogamy') in populations polymorphic for flower characteristics could provide the conditions for sympatric race formation, and this may have particular importance when it is accompanied by simultaneous ecological differentiation. Examples which appear to ilustrate this are to be found among the European Orchidaceae, in several species of which ecological races exist that differ from each other morphologically only in the allæsthetic features of the flowers.

Z. Lorković (Yugoslavia) spoke on "Die Merkmale der unvollendteten Speziationsstufe und die Frage der Einführung der Kathegorie der Semispezies in die Systematik". In the newer especially experimental systematics it is becoming increasingly common to find that two populations can be classified either as true species or as races, and that in one of them at least the inner reproductive isolation mechanism is not fully developed. He proposed, therefore, to denote such an incomplete degree in speciation as a new taxon, semispecies or prospecies. Otherwise there is the danger of concluding that species and race mix, which must lead not only to faulty systematics but also to false evolutionary inferences.

F. A. Schilder (Eastern Germany) followed with "Versuchleiner genetischen Klassification derVarianten bei Bänderschnecken". In the garden snail (Cepaea hortensis) variations in the shells are enormous, but there are great differences in frequency according to the presence or absence of certain genes in the populations. Though most varieties have been named scientifically, it seems to be more useful to design the characters of each specimen by a series of letters indicating its hereditary features in colour, banding, size, etc. When describing a population, the unit in biological evolution, one should indicate the percentage of varieties observed with regard to each independent character. The frequency of characters decreases concentrically from the locality where a character has been changed by mutation, and there seems to be scarcely any influence of environment on the progress of its distribution.

F. Ehrendorfer (Austria) in "Die geographische und ökologische Entfaltung des europäisch-alpinen Polyploidenkomplexes Galium anisophyllum Vill. seit Beginn des Quartärs" dealt with his cytogenetical and field-study research on this species. He stated that there were various polyploids $(2,4,6,8,10$. ploids) within the so-called species and related them to present-day ecological conditions and to those during and since the Glacial Epoch, and concluded that polyploids with the same chromosome number can arise in different ways.

B. Lövkvist (Sweden) dealt with the Cardamine pratensis complex in "Polyploidy and Ecological Differentiation". Chromosome numbers in purebreeding populations range from 16 to 96 and the cultivated material can be divided into two morphological groups: the Temperate Group in which all the numbers occur, and the Arctic Group with only the numbers 64 and 80 .

The components of the $C$. pratensis complex are ecologically well isolated from most other Cardamine species. New plants of all groups of the complex are self-ineompatible. Therefore if only a few immigrants grow in a locality the number of self-incompatible alleles need be quite small. As hybrids are completely fertile hybrid swarms arise.

Field studies in south Sweden showed that populations with different chromosome numbers have different ecological preferences. High water-content of soil is the main adaptation factor : another is the biotic factor of competition. Vegetative reproduction is widespread so that it is necessary to decide whether plants growing in a special niche belong to a clone or constitute a population.

The last paper of the session was "The Taxonomic Treatment of Vicarious Taxa" by $O$. Hedberg (Sweden). The gradual differentiation of one species population into two or more independent taxa is a very complicated process. It seems well established that the rate of evolution may be greater in some features than in others. Thus the degree of genetical isolation between two closely related taxa is not always proportional to the amount of differentiation in gross morphology, chromosome make-up, etc. It is therefore dangerous to rely upon genetical isolation as an unfailing eriterion for specific distinction. Though experimental methods are greatly aiding our understanding of many points in evolution they cannot be applied within the foreseeable future to more than a fraction of species described, and so to 
be able to write consistent accounts of floras we are compelled to retain the traditional taxonomic hierarchy.

When closely related taxa inhabit mutually exclusive areas the sole criterion for taxonomic distinction is the occurrence of discontinuous morphological variation. The taxonomic treatment of such 'geographically vicarious' taxa may often offer considerable difficulties.

Good examples are provided by the floras of the high East African mountains where the alpine biotas are completely isolated. Within several genera examples occur where the populations of different mountains are taxonomically distinguishable, forming groups of vicarious taxa. Recent studies have revealed numerous intermediate types which are difficult to classify. Some species occur in isolated populations on many or all of the mountains with no perceptible morphological differentiation; in others, different mountain populations of one species show statistical differences, but their variation-ranges overlap so as to make taxonomic distinction impossible; whereas in others there are distinctly discontinuous variation-ranges in one or more features. As a working rule the author chose to dernand clearly discontinuous variation in at least two independent characters for specific distinction, and one clear discontinuity for subspecific. But numerous intermediate stages of differentiation exist.

The last session began with a short account by J. Ramsbottom (Great Britain) of the precautions taken by the Linnean Society of London and by the British Museum (Natural History) for the protection of Linnaeus's collections during the Second World War.

F. Widder (Austria) then spoke on "Die geographisch-morphologische Methode als abgestufter Verwand tshaftstest".

H. Merxmüller (Western Germany) followed with "Einige Probleme der Sippengliederung und Arealbildung in den Alpen", in which he considered the so-called 'Tischler's rule' that in the flora of a given region there is a constantly increasing proportion of polyploids from south towards north. He gave reasons for holding that Tischler's rule must be restricted to two types of region-mountainous areas where the various biotypes widely separated in the plains come closely together, and regions strongly sculptured during the glacial epoch where different wandering floras could meet. It should, therefore, apply to the Alps, but many Swiss authors have concluded otherwise. The author thinks the discrepancy can be explained by regarding the heavily glacier-worn Central Alps and the bordering regions which were not glaciated, where old floras often of Mediterranean or Asiatic origin have been conserved, and often succeeded in re-entering the blanks left by the receding ice. This very considerable portion of old prediluvial types in the present alpine flora interferes with statistical results. The apparent failure of the rule is explained by the fact that the percentage of polyploids in the Alps has been compared with that of the regions north of them in Central Europe instead of the regions south, east and west, which were only slightly disturbed in the glacial period.

J. Iversen (Denmark) discussed "The Bearing of the Glacial and Interglacial Epochs on the Formation and Extinction of Plant 'Taxa". Conditions that favour the formation, or, reversely, the extinction, of plant species differed greatly in the course of one great cycle of glacial and postglacial (interglacial) succession. The period of maximum cold (full glacial) appears to have been purely destructive. The following stage was constructive, due to rising temperature combined with slight competition only ; light was adequate, the immature soil basic or neutral. Later, optimal temperature and soil conditions favoured dense forest growth; shade-intolerant species were suppressed or became rare relics. In the last stage the destruction of the flora was accelerated by climatic decline and soil degradation. Agriculture greatly modified this course, which applies to north-western Europe specifically.

G. E. Du Rietz (Sweden) speaking on "The Hybrid Concept" and illustrating his remarks with particular reference to New Zealand was concerned mainly with the nomenclature of what are generally known as hybrid swarms.

B. Petersen (Sweden) demonstrated "Pieris napi and $P$. bryoniae, two "Siamese twin species'". These species are sympatric in the Alps and in the Carpathians. In Scandinavia similar forms are allopatric and connected by geoclines. Common descent and not reproductive communication should in such a case be decisive for the taxonomic treatment of the group.

G. Svärdson (Sweden) continued the Swedish contributions with "Interspecific Hybrid Populations in Coreogonus". The morphological and ecological variation is great. The variation, however, is mostly environmental and only partly genetical. Therefore, to establish a firm basis for the study of speciation in this fish group, some characters must be found which are genetically determined and have only a low capacity for environmental modification. Experiments still in progress were begun in 1944. Special attention was paid to gill rakers as they have been used extensively in Coreogonus taxonomy.

If a whitefish population is transplanted to some new lake the morphology may be drastically changed, but the gill rakers are stable. If individual fish with extreme numbers of gill plates are selected and bred from, the progeny responds to the selection, indicating a polygenic inheritance of the gill raker numbers. Finally, if two sympatric or allopatric species of whitefish are artificially crossed, their hybrids are intermediate in gill rakers, again indicating polygenic inheritance.

Within the species-groups, introgression occurs very frequently and often in such abundance that the original species can no longer be identified with certainty. Introgression may be followed by replacement and the surviving population then shows some characters of the species which has disappeared.

As sibling species of whitefish and ciscoes have lived sympatrically in thousands of European lakes since the glaciers retracted, they cannot possibly be called a sub-species. Distribution data show that they have invaded the Scandinavian peninsula at different times and they certainly have an allopatric origin.

The final paper of the symposium was also by a Swede, B. Pejler, on "Taxonomical Studies on Planktonic Rotatoria". The local variation is often considerable. Sometimes a connexion exists between the local variation and the environment. At others a variation has been established which might best be explained as the result of introgressive hybridization between closely related species. The study of the 
variation within particular complexes of forms, which have previously been regarded as a single species, often reveals a discontinuity in size or other characters, indicating the occurrence of sibling species. By reason of certain facts it is assumed that the Rotatoria consist to a smaller degree of cosmopolitic forms than has been believed previously.

After the strenuous symposium it was a delight to be conducted along parts of Linnaeus's Herbatio gottsundensis by Prof. G. E. Du Rietz; it was described by Linnaeus in "Herbationes upsaliensis", 1753. Apart from the rich flora there was the satisfaction of seeing many plants which Linnaeus had demonstrated to his students. It was surprising to see Fritillaria meleagris growing in woodland. (On the journey back to headquarters the extensive 'King's Meadow' was visited, where it occurs in enormous numbers. It is there protected, and is so much an Upsala feature that it figures on the cover of the official guide.)

Other places of botanical interest were visited, and after lunch, Hammerby, Linnaeus's summer residence. Here there was a meeting of the Royal Society of Science of Upsala, and Prof. N. von Hofsten read a paper on "Linnaeus's Conception of Nature". Hammerby was looking at its best, and several of the plants introduced by Linnaeus were in full bloom.

The foreign members of the Symposium later all signed a memorandum recommending that Herbatio gottsundensis be set apart as a nature reserve.

Appropriately there was a dinner and reception in the evening at Smålands Nation, the student corporation of which Linnaeus was 'inspector'. An apple tree from his birthplace was planted in its 'native' soil, and the significance of this in Swedish lore explained by the inspector, Prof. C. Nylén, who later gave a short address on the Smålands Nation; Dr. A. Uggla spoke on Linnaeus as a Smålander and Mr. J. Beskow, the curator, on student life in Upsala.

'The end-of-term ceremonies with the 'promotions' of doctors were held on May 31. For the most part they followed tradition, beginning at 7 a.m. with a salute by cannon, one for each doctor, to be followed at 8 a.m. by bell-ringing from the cathedral. At 12 a.m. a procession was formed, and passed into the aula of the University, everyone in white tie and evening dress and the honorary doctors in academic robes : the order of procession gives nineteen entries, individuals and groups. The proceedings began with a discourse by Prof. S. Hörstadius, promoter of the Matematisk-naturvetenskapliga fakulteten, on "Linné, djuren och människan". To accompanying orchestral music those to be promoted were grouped in the five faculties, each with its own promoter; first the jubiles doctors (of fifty years standing), then the honorary doctors, finally those who had achieved success by thesis. The name is called, the three steps of the cathedra superior ascended, a laurel crown (or a top-hat) placed on the head (accompanied by a cannon-shot without), a gold ring put on the finger, a diploma presented, a shake of the hand, a descent from the cathedra and a pause and a bow to H.M. the King of Sweden, who sat just below the platform. The three-hour ceremony was impressive and picturesque with its savour of the medieval and its national significance: it ended with the students acclaiming the jubilee and honorary doctors assembled on the steps of the University in song and speech.
The programme of the ceremony was adorned with a representation of a laurel wreath surrounding Linnaea borealis and the words "Tantus amor florum". It includes the "Promotions-formulär" employed by Linnaeus for the medical faculty on October 31,1754

Among the recipients of honorary degrees (Fil.Dr.) were H. H. Allan (New Zealand), Julian Huxley and J. Ramsbottom: A. H. Uggla, the well-known authority on Linnaeus, was promoted doctor of medicine.

Attention should be directed to the "Inbjudningar till Doktors-Promotionerna", as it has an appendix of four important papers : F. Berg, "Linnés Systema morborum" (132 pp.); A. Liljencrantz, "Kungl. Vetenskaps-Societetens protokoll 1732-1784" (97 pp.) ; G. E. Du Rietz, "Linné som myrforskare"' (80 pp.) and $\AA$. Holm, "Specimina Linnaeana i Uppsala bevarade zoologiska samlingar från Linnés tid" (68 pp.).

The menu card at the graduation dinner held in the Castle was a reproduction of the frontispiece to the rare "Linnéska Institutets Skrifter"-a few hand-coloured copies of this were found recently in the archives of the Royal Society of Sciences, Upsala.

The celebrations ended on June 2 with a commemoration meeting of the Swedish Linnean Society at Hammerby. The annual pilgrimage this year marked also the fortieth anniversary of the Society. The President repeated his discourse of Thursday, though this time in Swedish: he was followed by A. G. Boerman, a Dutch medical man, who attempted an analysis of Linnaeus's character by reference to his youthful notes and writings. In glorious weather about two hundred had an alfresco lunch, at the end of which the veteran student of Linnaeus, Prof. Robert Fries, spoke of the beginning of the Society of which he was co-founder, of its objects and of the Linnean tradition. The meeting ended at Linnaeus's old house and garden at Upsala-the headquarters of the Society.

It was a memorable week, and all who took part in the celebrations will long remember the courteous and lavish hospitality of our Swedish hosts, the understanding tributes to Linnaeus, the international friendliness of the symposium-and Upsala in spring.

\section{NATURAL RUBBER INDUSTRY RESEARCH AND DEVELOPMENT}

$\mathrm{T}$ HE natural rubber industry is made up of units varying enormously in size, ranging from very large estates with their own modern and well-equipped factories to smallholdings, some processing their rubber in primitive fashion, others making use of co-operative equipment. The organization of research and development schemes to assist these diverse elements began naturally enough with the creation, in Ceylon and Malaya, of institutes concerned in the main with agronomic problems and with the provision of advice to growers. The success of these institutes is reflected in the substantial increases in yield-per tree or per acre-which are now being obtained, and in a steady advance in the general. quality of the rubber produced. 